\title{
Predation by drilling gastropods and asteroids upon mussels in rocky shallow shores of southernmost South America: paleontological implications
}

Sandra Gordillo and Fernando Archuby

Acta Palaeontologica Polonica 57 (3), 2012: 633-646 doi: http://dx.doi.org/10.4202/app.2010.0116

To achieve a better understanding of predation pattern recorded in the fossil record it is essential to study predator-prey interactions in the modern seas. It includes the data collected from the field observations as well as from the experiments in captivity. Such an approach allows recognition of the bioeroders, its description and also provides quantification of these interactions. This work offers a case study of the traces of predation resulting from the predator-prey interactions between three mussels: Mytilus chilensis, Brachidontes purpuratus, and Aulacomya atra; and their five natural enemies: the gastropods Trophon geversianus, Xymenopsis muriciformis, and Acanthina monodon, and the asteroids Cosmasterias lurida and Anasterias antarctica living along the intertidal and/or subtidal rocky shores in Tierra del Fuego. The predatory damage to mussel shells varies according to the predator and prey species and techniques for attacking prey are highly specialized. A. monodon drills a hole in $B$. purpuratus but uses the outer lip of its shell as a wedge to open the valves of $M$. chilensis and A. atra. T. geversianus always makes holes, but while it drills the valve walls of $M$. chilensis, it prefers to drill the valve edges of A. atra and B. purpuratus, with different characteristic patterns. Usually the shells of mussels killed by $C$. lurida do not suffer from any mechanical damage, but some other shells were crushed or fractured along the margins. Comparatively, time required to successfully attack a prey was shorter in C. lurida (24 hours), followed by $A$. monodon (36 hours), and longer in $T$. geversianus (9 to 10 days). Traces of predation are not randomly distributed across size classes of mussel prey, reflecting selectivity for a particular size class. Also, drill holes are usually placed at specific sectors of the shell, indicating site selectivity. These observations offer some paleontological implications for investigating the pattern of predation in fossil record. They show that different patterns of shell damage can be due to different predator species (e.g., wall vs. edge drillings), although the same predator species can leave different marks when consuming different prey (e.g., T. geversianus). Most disconcerting for paleontologists are cases of predation which do not leave any marks on the prey shell detectable in the fossil record (e.g., predation by asteroids), or leave ambiguous marks (A. monodon when preying with the spine). In conclusion, besides the opportunity to identify some traces of predation by drilling gastropods in fossil mussels, this work gives criteria to address predation in some particular paleontological cases that would otherwise be dismissed by researchers. 
Key words: Bivalvia, Gastropoda, Asteroidea, predation, prey selection, taphonomy, Tierra del Fuego, Argentina.

Sandra Gordillo [sgordillo@efn.uncor.edu], Centro de Investigaciones en

Ciencias de la Tierra, Consejo Nacional de Investigaciones Científicas y

Técnicas (CICTERRA, CONICET); Centro de Investigaciones

Paleobiológicas (CIPAL), Facultad de Ciencias Exactas, Físicas y

Naturales, Universidad Nacional de Córdoba. Av. Vélez Sársfield 299

X5000JJC Córdoba, Argentina, Fernando Archuby [farchuby@fcnym.unlp.edu.ar], Facultad de Ciencias

Naturales y Museo, Universidad Nacional de La Plata, Argentina.

This is an open-access article distributed under the terms of the Creative Commons Attribution License (for details please see creativecommons.org), which permits unrestricted use, distribution, and reproduction in any medium, provided the original author and source are credited. 